\title{
Pembaharuan Kebijakan Hukum Pidana Terkait Beban Pembuktian Pada Tindak Pidana Korupsi Dalam Rangka Pengembalian Kerugian Keuangan Negara
}

\author{
Oleh: Afrianto Sagita* \\ Dosen Tetap Fakultas Hukum Universitas 17 Agustus 1945 Jakarta \\ Jalan Sunter Permai, Tanjung Priok, Jakarta Utara
}

\begin{abstract}
Abstrak
Tujuan penelitian ini untuk untuk menjelaskan pembaharuan kebijakan hukum pidana terkait beban pembuktian yang dapat digunakan sebagai istrumen hukum dalam rangka pengembalian kerugian keuangan negara. Penelitian ini termasuk jenis penelitian hukum normatif/yuridis normatif, yang dilakukan dengan cara meneliti bahan pustaka atau data sekunder. Hasil penelitian ini menjelaskan bahwa asas praduga bersalah (presumtion of guilty) dipandang sangat urgen untuk dimuat dalam Undang-Undang Pemberantasan Tindak Pidana Korupsi (UUPTK) dan urgen diterapkan dengan segera. Penerapan asas praduga bersalah, sebaiknya dibatasi hanya dalam hal pembuktian di persidangan sajamelalui metode pembalikan beban pembuktian. Penerapan asas praduga bersalah melalui metode pembalikan beban pembuktian tersebutdiharapkan mampu mengeliminasi tingkat kesulitan pembuktian yang dihadapi dalam pemberantasan tindak pidana korupsi.Selayaknya,sistem pembalikan beban pembuktiandijadikan asas pondasi/landasan filosofis dalam payung hukum UUPTK. Kemudian dari tataran asas diturunkan menjadi norma, sehingga ketentuan mengenai pembalikan beban pembuktian dapat dicantumkan dalam klausul pasal demi pasal dalam UUPTK. Aturan-aturan hukum dalam rangka pemberantasan korupsi pun seharusnya selalu dikembangkan secara progresif sesuai perkembangan zaman, agar tidak ketinggalan dan kalah dengan modusmodus korupsi yang semakin mutakhir.
\end{abstract}

\section{Kata Kunci: Kebijakan HukumPidana, Beban Pembuktian, Tindak Pidana Korupsi}

\begin{abstract}
The purpose of this study is to explain the renewal of criminal law policies related to the burden of proof that can be used as legal instruments in the context of returning losses to state finances. This study includes the type of normative / normative legal research, which is done by examining library materials or secondary data. The results of this study explain that the presumption of guilty principle is seen as very urgent to be contained in the Law on the Eradication of Corruption (UUPTK) and urgently applied immediately. The application of the presumption of guilt principle, should
\end{abstract}

*Penulis korespondensi e-mail: afriantosagitamanurung@gmail.com 
be limited only in the case of evidence at the trial only through the proof of reversal method. The application of the principle of presumption of guilt through the method of reversing the burden of proof is expected to be able to eliminate the level of evidence difficulties faced in eradicating criminal acts of corruption. Appropriately, the system of reversing the burden of proof is used as a philosophical foundation I foundation in the legal umbrella of the UUPTK. Then from the basic level it is reduced to the norm, so that the provisions regarding reversal of the burden of proof can be included in the clause article by article in the UUPTK. Legal rules in the context of eradicating corruption should always be developed progressively according to the times, so as not to lag behind and lose the modes of corruption that are increasingly current.

\section{Keywords: Criminal Law Policy, Burden of Proof, Corruption Crime}

\section{Pendahuluan}

Secara umum korupsi dipicu olehcorruption by greed (keserakahan), corruption by need (kebutuhan), dan corruption by chance (peluang). ${ }^{1}$ Adakalanya pemicu tersebut menyatu dan dapat menimbulkan kerugian yang lebih hebat. Dalam konteks kekinian tindak pidana korupsi merupakan salah satu tindak pidana yang dikategorikan sebagai tindak pidana yang luar biasa (extra ordinary crime). Sebagai suatu tindak pidana yang luar biasa, korupsi telah mengakar di dalam kehidupan masyarakat Indonesia. Bahkan, kebiasaan korupsi telah menyusup dan menyatu kedalam sistem penyelenggaraan pemerintahan di negara ini. Gurita korupsi semakin kuat melilit negeri ini. Segala upaya yang telah dilakukan dapat dikatakan gagal menahan dan memberantas laju korupsi.
Sampai sejauh ini, praktik korupsi tidak ada matinya. $^{2}$

Korupsi dipandang sebagai biang keladi krisis ekonomi berkepanjangan di Indonesia. Korupsi merupakan perbuatan yang sangat tercela, terkutuk dan sangat dibenci oleh masyarakat. Korupsi telah merusak sistem dan institusi sosial, ekonomi, mental dan citra aparatur negara. Indonesia mengalami sulitnya memberantas korupsi yang terjadi diseluruh instansi dan kegiatan pembangunan, karena pelakunya menggunakan variasi modus operandi. ${ }^{3}$ Kegagalan pemerintah dalam memberantas korupsi semakin memperburuk citra pemerintah dimata masyarakat. Hal itu tercermin dalam bentuk ketidakpercayaan masyarakat terhadap penegakan hukum, sehingga saat ini Indonesia berada dalam era ketidakpastian penegakan hukum.

${ }^{1}$ Majelis Tarjih dan Tajdid PP Muhammadiyah, Fikih Anti Korupsi Perspektif Ulama Muhammadiyah, (Jakarta: Pusat Studi Agama dan Peradaban, 2006, hlm. 14.

2Saldi Isra, Membinasakan Korupsi dalam Harian Kompas 2 Maret 2011.

${ }^{3}$ Feri Wibisono, Menyongsong Era Baru Pemberantasan Tindak Pidana Korupsi, Media Hukum, Volume 1, Nomor 2, 2002, hlm. 70. 
Apabila tak ada perbaikan maka akan sangat membahayakan kelangsungan hidup bangsa. ${ }^{4}$

Romli Atmasasmita menekankan bahwa jika dikaji dari dampak negatifsejak pemerintahan Orde Baru sampai saat ini jelas bahwa perbuatan korupsi merupakan perampasan hak ekonomi dan hak sosial rakyat Indonesia. ${ }^{5}$ Hidayat Nurwahid pernah berkomentar koruptor adalah the real terrorists, sedangkan, Kwik Kian Gie terus berargumen, corruption is the roots of all evils. ${ }^{6}$

Kondisi kontemporer penanganan tindak pidana korupsi telah mencapai titik nadir dalam rangka pencegahan dan pemberantasannya. Korupsi menimbulkan kejemuan, banyak kerugian negara yang tidak bisa lagi didata. Dari beberapa tindak pidana korupsi, dapat dipantau bahwa terdapat suatu jaringan seperti "benang kusut" dalam pemberantasan tindak pidana korupsi yang akhirnya melahirkan sindiran berupa "maling teriak maling" antara sesama pelaku tindak pidana korupsi.

Selama tindak pidana korupsi merajalela di suatu negara maka negara tersebut akan sangat sulit berkembang ke fase negara maju. Edgargo Buscaglia dan Maria Dakolias ${ }^{7}$ sebagaimana dikutip Denny Indrayana berpendapat di dalam tulisannya An Analysis of the Causes of Corruption in Judiciary:

"Corruption is an intrinsic part of the way the state operate in many countries, and it is impossible to remodel the state while it persist. Fighting corruption is therefore central to the process of reinvigorating the statefailure to confront it will obstruct reform initiates and prolong the high social and economic cost it brings".

Berikut ini disajikan data Indeks Persepsi Korupsi (IPK) Indonesia mulai dari tahun 2013 sampai dengan tahun 2017. Pada tahun 2013 Transparency International (TI) meluncurkan Corruption Perception Index (CPI) 2013 secara serentak di seluruh dunia. Survei ini mengingatkan bahwa korupsi fenomena global di dunia dengan tingkat kerawanan yang berbeda-beda. Krisis ekonomi global merupakan indikator konkrit tidak adanya transparansi dan akuntabilitas di sektor bisnis membuka peluang terhadap korupsi, ternyata mampu menyebabkan efek domino yang dapat menghancurkan tata ekonomi dunia. Indeks pengukuran memiliki skala antara 0 (sangat korup) sampai dengan 100 (sangat bersih).

Skor Indonesia dalam CPI 2013 adalah 32, dengan skor ini indonesia menempati hIm. 5-10.

${ }^{4}$ KPK, Buku I Rencana Stratejik KPK 2008-2011, (Jakarta: Komisi Pemberantasan Korupsi, 2008),

${ }^{5}$ Lilik Mulyadi, Tindak Pidana Korupsi di Indonesia Normatif, Teoritis, Praktik dan Masalahnya, (Bandung: Alumni, 2007), hlm. 252. Lihat juga Romli Atmasasmita, Korupsi, Good Governance dan Komisi Anti Korupsi di Indonesia, (Jakarta: Badan Pembinaan Hukum Nasional Departemen Kehakiman dan HAM RI, 2002), hlm. 25.

${ }^{6}$ Denny Indrayana, Negeri Para Mafioso: Hukum di Sarang Penyamun, (Jakarta: Kompas, 2008), hIm. 9.

7lbid. 
peringkat 144 negara terkorup di dunia berdasarkan pengukuran CPI 2013 terhadap 177 negara di dunia. Skor ini dapat dibaca bahwa Indonesia masih dipandang rawan korupsi oleh para pelaku bisnis maupun pengamat atau analis negara. Skor Indonesia yang sangat rendah menunjukkan bahwa usaha pemberantasan korupsi masih jauh dari berhasil. Hal ini sangat memprihatinkan apalagi bila skor Indonesia dibandingkan dengan negara-negara tetangga, seperti Singapura menempati peringkat 5 dengan skor 87, Brunei Darussalam menempati peringkat 38 dengan skor 55, Malaysia menempati peringkat 53 dengan skor 49, dan Thailand menempati peringkat 102 dengan skor $37 .{ }^{8}$

Skor CPI atau Indeks Persepsi Korupsi (IPK) Indonesia tahun 2014 adalah 34, skor ini naik dua angka dari skor 2013, yaitu $32 .{ }^{9}$ Sementara,lembaga TI mengumumkan adanya perbaikan indeks persepsi korupsi CPI Indonesia untuk tahun 2015. Berdasarkan temuan lembaga $\mathrm{TI}$, skor CPI Indonesia untuk 2015 mencapai 36, jumlah tersebut meningkat dua poin dibanding skor CPI 2014, yaitu 34. ${ }^{10}$ Skor CPI Indonesia untuk 2016 mencapai 37, dengan skor ini indonesia menempati peringkat 90 negara terkorup di dunia berdasarkan pengukuran CPI 2016 terhadap 176 negara di dunia. ${ }^{11}$ Skor ini dapat dibaca bahwa Indonesia masih dipandang rawan korupsi oleh para pelaku bisnis maupun pengamat atau analis negara. Transparency International Indonesia (TII) juga merilis skor CPI atau IPK Indonesia tahun 2017. Hasil survei TII menunjukkan skor IPK Indonesia berada pada angka 37 dan berada diperingkat 96 dari 180 negara yang disurvei. ${ }^{12}$

Skor IPK berada pada rentang $0-100$, angka 0 berarti negara dipersepsikan sangat korup, sementara skor 100 berarti dipersepsikan bersih dari korupsi. CPI Indonesia tahun 2017 berada di skor 37. Angka ini sama dengan perolehan skor tahun 2016. Hal ini berarti skor IPK Indonesia tidak mengalami peningkatan ataupun penurunan jika dibandingkan skor tahun 2016.

Kondisi ini memberikan gambaran bahwa betapa korupsi di Indonesia sudah sangat kronis, dapat menjadi salah satu kendala serius dalam membenahi krisis multidimensi di Indonesia. ${ }^{13}$ Dari perspektif internasional, pada dasarnya korupsi merupakan salah satu kejahatan dalam klasifikasi white collar crime dan mempunyai akibat kompleksitas serta menjadi perhatian

\footnotetext{
${ }^{8} \mathrm{http}: / /$ www.transparency.org/cpi2013/results, diakses tanggal 24 Maret 2017.

${ }^{9} \mathrm{https}: / /$ news.detik.com/berita/d-2766634/skor-indeks-persepsi-korupsi-indonesia-2014-lebih-baik-daritahun-sebelumnya?nd771104bcj=\&nd771104bcj=, diakses tanggal 24 Maret 2017.

${ }^{10} \mathrm{ht} \mathrm{tps://nasional.kompas.com/read/2016/01/27/15053181/}$ Indeks.Persepsi.Korupsi.Indonesia.Membaik., diakses tanggal 24 Maret 2017.

${ }^{11} \mathrm{http}: / / \mathrm{ww}$.transparency.org/news/feature/corruption_perception_index_2016, diakses tanggal 24 Maret 2017.

${ }^{12} \mathrm{http}: / /$ nasional.kompas.com/read/2018/02/22/23550051/skor-ipk-tak-meningkat-agendapemberantasan-korupsi-dinilai-stagnan, diakses tanggal 23 Februari 2018.

${ }^{13}$ Alpiner Sinaga, Korupsi, Bias dan Strategi Penyidikan, (Jakarta: Markas Besar Kepolisian Negara Republik Indonesia, 2005), hlm. 1.
} 
masyarakat Internasional. ${ }^{14}$ Ban Ki-Moon (Sekretaris Jendral PBB) menegaskan bahwa "harta negara yang dikorupsi dapat membiayai program sosial dan infrastruktur publik". ${ }^{15}$ Korupsi di suatu negara bukan lagi masalah negara itu sendiri, tetapi sudah menjadi masalah atau kepedulian semua negara di dunia. ${ }^{16}$ Indriyanto Seno Adji mengatakan: ${ }^{17}$

"Dalam konteks yang komprehensif, tidak dapat dipungkiri lagi bahwa korupsi merupakan white collar crime dengan perbuatan yang selalu mengalami dinamisasi modus operandinya dari segala sisi sehingga dikatakan sebagai invisible crime yang sangat sulit memperoleh prosedural pembuktiannya, karena seringkali memerlukan pendekatan sistem (Systemic Approach) terhadap pemberantasannya". ${ }^{18}$

Perbuatan korupsi dilakukan mulai dari "mark up" pengadaan barang dan jasa, pengadaan barang dan jasa yang menyalahi prosedur, penyalahgunaan wewenang, suap, pemberian atau penerimaan gratifikasi, penggunaan dana yang tidak sesuai dengan "posting" anggaran yang semuanya itu mempunyai potensi merugikan keuangan dan perekonomian negara. ${ }^{19}$

Mantan ketua Komisi Pemberantasan Korupsi (KPK) Abraham Samad mengatakan, kasus korupsi di Indonesia mengalami metamorfosa dan regenerasi. Metamorfosa itu terlihat dari perkembangan modus korupsi yang sebelumnya masih dalam bentuk pungutan liar (pungli), namun kemudian berkembang menjadi "kera putih" hingga pencucian uang. Sementara mengenai kasus korupsi yang sudah beregenerasi, karena sebelumnya oknum pelakunya rata-rata berusia 40-50 tahun, namun kini sudah dilakukan oleh generasi muda. Mencermati fenomena tersebut, dia mengatakan, korupsi sudah mewabah dan sangat memprihatinkan karena itu KPK harus memiliki metode untuk memberantas korupsi. ${ }^{20}$ Oleh sebab itu, KPK dituntut untuk tidak lagi menggunakan cara-cara konvensional dalam menangani kasus korupsi yang masif, tetapi harus menggunakan cara yang progresif dan radikal.

Beberapa kasus korupsi yang merugikan negara dalam jumlah besar yang

${ }^{14} \mathrm{~A}$. Djoko Sumaryanto, Pembalikan Beban Pembuktian Tindak Pidana Korupsi dalam Rangka Pengembalian Kerugian Keuangan Negara, (Jakarta: Prestasi Pustakaraya, 2009), hlm. 1.

${ }^{15}$ Ibid.

${ }^{16} \mathrm{lbid}$. Lihat juga M. Fadjroel Rachman, Rekor Koruptor, Harian Kompas, 20 September 2007, hlm. 6.

${ }^{17}$ Indryanto Seno Adji, Problematika Korupsi dan Antisipasinya Melalui Sistem Hukum Pidana, makalah disampaikan dalam seminar yang diadakan oleh Puslitbang Kejaksaan Agung RI pada 21 Oktober 2003, hIm. 1.

${ }^{18} \mathrm{Ibid}$.

${ }^{19}$ A. Djoko Sumaryanto, Pembalikan Beban...Op.Cit., hlm. 3. Lihat juga Nur Basuki Minarno, Pembuktian Gratifikasi dan Suap dalam Tindak Pidana Korupsi, Yuridika, Majalah Fakultas Hukum UNAIR, Volume 20, Nomor 2 Maret 2005.

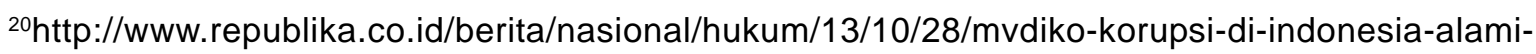
metamorfosa-dan-regenerasi, diakses tanggal 24 Maret 2017. 
belum terungkap, pada umumnya melibatkan pejabat negara dan penegak hukum yang punya kekuatan politik. Berikut ini penulis sajikan contoh 5 kasus korupsi dalam jumlah besar, ${ }^{21}$ yang masih simpang siur dan belum terselesaikan.

Kasus Cendana, penyelidikan kasus ini dimulai tahun 1998, setelah ditemukannya indikasi penyelewengan dana dari berbagai yayasan yang dikelola oleh keluarga Cendana. Peraturan Pemerintah di tahun 1976 memang menetapkan penggunaan sisa laba bersih dari bank-bank milik Pemerintah harus disumbangkan sebesar $5 \%$ setiap tahunnya ke yayasan-yayasan yang dikelola mantan Presiden Soeharto. Kasus ini tenggelam di tahun 2000, ketika kesehatan Soeharto terus menurun dan minimnya bukti-bukti yang ditemukan. Babak baru kasus ini dimulai kembali di tahun 2007, saat Kejaksaan Agung kembali mendaftarkan Soeharto pemimpin dari Yayasan Supersemar sebagai terdakwa ke Pengadilan Negeri (PN) Jakarta Selatan. Pada bulan Juli 2015, Mahkamah Agung mengabulkan PK (Peninjauan Kembali) Jaksa dan memvonis keluarga Cendana untuk membayar ganti rugi 4,4 triliun kepada negara. Hingga saat ini, masih banyak pihak yang yakin bahwa kasus ini belum tuntas dan masih banyak lagi kerugian negara yang tidak terungkap akibat korupsi dari Soeharto dan keluarganya.

Kasus Hambalang, proyek pusat olahraga di Hambalang, Bogor dimulai pada bulan oktober tahun 2009, saat Kementerian Pemuda dan Olahraga (Kemenpora) menilai perlu ada Pusat Pendidikan Latihan dan Sekolah Olah Raga pada tingkat nasional. Proyek ini didirikan diatas lahan sebesar 32 hektar dan menelan dana 2,5 triliun. Proyek ini terhenti di tahun 2012 dengan alasan penyelewengan dana yang masif ke sejumlah pejabat publik. Hingga kini kasus ini masih ditangani oleh KPK dan lokasi proyek di Hambalang, Bogor kini menjadi puing-puing setengah jadi yang tidak terurus.

Kasus Bank Century, adalah skandal korupsi besar dengan dampak yang cukup parah bagi sistem perbankan Indonesia. Bank Century yang divonis sebagai bank gagal, mendapatkan "perlakuan istimewa" dari Pemerintah melalui kucuran dana secara cuma-cuma dari Bank Indonesia. Hal ini menyebabkan Pemerintah mengalami kerugian sebesar 6,7 triliun rupiah dalam bentuk bantuan modal. Bantuan dana ini mengalir begitu saja secara bertahap dari bulan November 2008 sampai Juli 2009 ke Bank yang sudah terbukti lumpuh ini. Kasus ini menuai pro dan kontra yang luas. Ada banyak tudingan dan kecurigaan dari publik yang beranggapan aliran dana untuk Bank Century bukanlah semata-mata untuk menyelamatkan sistem perbankan Indonesia, tetapi karena benturan politis, yaitu menyelamatkan deposan-deposan besar yang melibatkan banyak pejabat negara. Hingga saat ini, otak utama di balik skandal

\footnotetext{
${ }^{21}$ http://indonesiaone.org/5-korupsi-besar-di-indonesia-yang-masih-simpang-siur-dan-belumterselesaikan, diakses tanggal 26 Juni 2018.
} 
Century belum terungkap, bahkan lenyap ditelan bumi.

\section{Kasus Bantuan Likuiditas Bank} Indonesia atau yang dikenal dengan singkatan BLBI, adalah skema bantuan pinjaman dari Bank Indonesia kepada 48 bank swasta yang mengalami masalah likuiditas saat krisis moneter di tahun 1998. Kebijakan BLBI ini kemudian menjadi suatu skandal mega korupsi yang tergolong extraordinary crime/kejahatan luar biasa karena banyaknya penyelewengan dana dan berdampak sangat besar bagi sendi-sendi perekonomian bangsa. Menurut audit Badan Pemeriksaan Keuangan (BPK) di tahun 2000 , negara mengalami kerugian sebesar 138,44 triliun dari 144,53 triliun yang disalurkan lewat dana BLBI. Bahkan kerugian negara jika dihitung dari biaya penyehatan perbankan sepanjang tahun 1997-2004 mencapai Rp 640,9 triliun. Meskipun jumlah kerugian negara sangat fantastis, ironisnya kasus ini justru seperti lenyap begitu saja tanpa penanganan serius dari Pemerintah. Dengan modus operandi yang sangat rapi dan tidak pernah terselesaikan hingga saat ini. Kasus yang sangat rumit ini memang diindikasi melibatkan banyak pejabat elit dan para konglomerat, sehingga butuh kekuatan besar dan niat yang kuat dari seluruh elemen bangsa untuk menuntaskan skandal korupsi tersebut. Aktor intelektual dari kasus ini juga tidak tersentuh dan terjerat oleh hukum.

Kasus E-KTP, merupakan praktik korupsi yang masif dan sangat terstruktur.
Banyak kalangan yang menduga, bahwa proyek tersebut memang sudah direncanakan untuk dapat dikorupsi disana sini. Kasus yang merugikan negara sebesar 2,3 triliun rupiah ini bermula di akhir Oktober 2009, saat Kementerian Dalam Negeri (Kemendagri) mengajukan anggaran sebesar 6,9 triliun rupiah untuk penyelesaian Sistem Informasi Administrasi Kependudukan (SIAK) yang salah satu komponennya adalah Nomor Induk Kependudukan (NIK). Pada tahun 2011 lelang proyek e-KTP pun dilakukan. Kasus ini muncul kepermukaan setelah mantan bendahara umum Partai Demokrat M. Nazzarudin mulai buka kartu di tahun 2014. Kasus ini sedang terus diusut dan diproses oleh KPK dan tampaknya masih akan melewati perjalanan yang panjang, karena sampai saat ini aktor intelektual dari kasus ini tak kunjung tersentuh dan terjerat hukum.

Selain 5 kasus korupsi di atas juga ada kasus dugaan korupsi mantan Ketua BPK Hadi Poernomo yang tidak bisa tersentuh hukum. KPK menetapkan Ketua Badan Pemeriksa Keuangan (BPK) Hadi Poernomo sebagai tersangka kasus dugaan korupsi terkait pembayaran pajak PT Bank Centra Asia (BCA). Kasus ini berawal ketika BCA mengajukan keberatan pajak atas transaksi non performance loan (kredit bermasalah) sekitar 17 Juli 2003. Nilai transaksi bermasalah PT Bank BCA ketika itu sekitar Rp 5,7 triliun. ${ }^{22}$ BCA Tbk dalam hal ini mengajukan keberatan pajak atas transaksi non performance loan sebesar Rp

${ }^{2}{ }^{2} \mathrm{ht}$ t p s: / / n a sional. kompas.com / read/2014/04/21/1929221/ Ini.Detail.Kasus.Dugaan.Korupsi.Pajak.yang.Menjerat.Hadi.Poernomo, diakses tanggal 26 Juni 2018. 
5,7 triliun kepada Direktorat PPh (Pajak Penghasilan). Kemudian, surat diterima PPh maka dilakukan pengkajian lebih dalam untuk bisa mengambil kesimpulan. Setelah melakukan kajian selama hampir setahun, pada 13 Maret 2004, Direktorat PPh menerbitkan surat yang berisi hasil telaah mereka atas keberatan pembayaran pajak yang diajukan PT BCA. Surat tersebut berisi kesimpulan PPh bahwa pengajuan keberatan pajak BCA harus ditolak. Direktur PPh menyampaikan kepada Dirjen Pajak dalam kesimpulannya bahwa permohonan wajib pajak BCA harus ditolak. Namun, pada 18 Juli 2004, Hadi selaku Direktur Jenderal (Dirjen) Pajak ketika itu justru memerintahkan Direktur PPh untuk mengubah kesimpulan. Melalui nota dinas tertanggal 18 Juli 2004, kata Abraham, Hadi diduga meminta Direktur PPh untuk mengubah kesimpulannya sehingga keberatan pembayaran pajak yang diajukan PT Bank BCA diterima seluruhnya.

Atas dasar inilah KPK menjerat Hadi dengan Pasal 2 ayat (1) dan atau Pasal 3 Undang-Undang Pemberantasan Tindak Pidana Korupsi juncto Pasal 55 ayat (1) ke1 KUHP. Atas perbuatan Hadi ini, negara diduga mengalami kerugian sekitar 375 miliar rupiah. Hadi ditetapkan sebagai tersangka oleh KPK pada 21 April 2014 atas kasus dugaan korupsi terkait penerimaan permohonan keberatan pajak oleh PT BCA tahun 1999. la diduga merugikan keuangan negara sebesar Rp 375 miliar karena mengabulkan keberatan pajak tersebut saat ia masih menjabat sebagai Dirjen Pajak tahun 2002-2004. Hadi mengajukan gugatan praperadilan. Pra peradilan diregisterpada 16 Maret 2015 dengan nomor registrasi 21/ Tik.Trap/2015/PNJKTSel, dan pada tanggal 26 Mei 2015Hakim tunggal Haswandi mencabut status tersangka Hadi. Haswandi juga merupakan Ketua Pengadilan Negeri (PN)Jakarta Selatan (Jaksel) dan kini menjadi Direktur Promosi dan Mutasi di MA. Selain itu, Haswandi juga memutuskan: ${ }^{23}$

1. Penyitaan barang yang dilakukan KPK atas Hadi tidak sah.

2. Menyatakan tidak sah segala keputusan atau penetapan yang dikeluarkan lebih lanjut oleh KPK berkenaan dengan penetapan tersangka Hadi Poernomo.

Atas putusan PN Jaksel tersebut, KPK mengajukan Peninjauan Kembali. Pada 16 Juni 2016Mahkamah Agung menyatakan PN Jaksel tidak berwenang menghentikan penyidikan KPK terhadap Hadi Poernomo. Namun hingga saat ini, Hadi Poernomo juga tak kunjung tersentuh dan terjerat oleh hukum.

Hampir dua abad yang lalu, Lord Acton (John Emerich Edward Dalberg-Acton) dalam suratnya kepada Bishop Mandell Creighton menulis sebuah ungkapan yang menghubungkan antara "korupsi" dengan "kekuasaan," yakni "Power tends to corrupt, and absolute power corrupts absolutely," bahwa "Kekuasaan cenderung untuk korupsi dan kekuasaan yang absolut cenderung

${ }^{23} \mathrm{https}$ //news.detik.com/berita/d-3446171/jejak-hadi-poernomo-lolos-dari-tersangka-dan-kalahkankemenkeu, diakses tanggal 26 Juni 2018. 
korupsi absolut". ${ }^{24}$ Setidaknya hal tersebut tercermin dalam uraian beberapa contoh kasus-kasus korupsi yang telah dipaparkan di atas bahwa seseorang yang mempunyai jabatan, kewenangan dan kekuasaan, lebih dominan dan cenderung untuk melakukan perbuatan korupsi. Kasus-kasus korupsi yang mengakibatkan kerugian negara dalam jumlah besar justru lebih banyak dilakukan dalam lingkaran eksekutif, legislatif dan yudikatif. Lahirnya Undang-Undang No. 31 Tahun 1999 Jo. Undang-Undang No. 20 Tahun 2001 tentang Tindak Pidana Korupsi (UUPTK) bertujuan untuk menanggulangi dan memberantas tindak pidana korupsi serta bertujuan untuk se-efisien dan seefektif mungkin dapat mengurangi dan mengembalikan kerugian keuangan negara yang ditimbulkan oleh perbuatan korupsi tersebut.

UUPTK menerapkan pembalikan beban pembuktian yang bersifat terbatas dan berimbang. Dalam artian bahwa terdakwa mempunyai hak untuk membuktikan bahwa ia tidak melakukan tindak pidana korupsi dan wajib memberikan keterangan tentang seluruh harta bendanya dan harta benda istri atau suami, anak, dan harta benda setiap orang atau korporasi yang diduga mempunyai hubungan dengan perkara yang bersangkutan dan penuntut umum tetap berkewajiban membuktikan dakwaannya.

Elwi Danil berpendapat dalam di dalam tulisannya bahwa:"Pembalikan beban pembuktian atau "omkering van de bewisjlast" (the reversal of the burden of proof), yang sering juga disebut sistem pembuktian terbalik, secara umum dapat dipahami sebagai suatu sistem yang meletakkan beban pembuktian di tangan terdakwa untuk membuktikan bahwa ia tidak bersalah melakukan tindak pidana yang didakwakan kepadanya". ${ }^{25}$

Dalam hal terdakwa tidak berhasil membuktikan bahwa ia tidak bersalah, maka ia dinyatakan bersalah melakukan tindak pidana. Sementara, penuntut umum dibebaskan dari kewajiban pembuktian. ${ }^{26}$ Hanya karena alasan pembuktian yang sulit, betapa banyak koruptor di Indonesia yang selama ini tidak tersentuh oleh ketentuanketentuan hukum pidana. Mereka cenderung berlindung di balik asas praduga tak bersalah (presumption of innocence), bahkan dapat dikatakan telah "dimanjakan" oleh asas hukum pidana itu sendiri, sehingga kepentingan masyarakat banyak terabaikan. ${ }^{27}$ Untuk menutupi kelemahan tersebut sudah seharusnya memberi ruang agar asas praduga bersalah (presumtion of guilty)

${ }^{24}$ Ermansjah Djaja, Tipologi Tindak Pidana Korupsi di Indonesia, (Bandung: Mandar Maju, 2010), hlm. 1. Lihat juga Romli Atmasasmita, Sekitar Masalah Korupsi Aspek Nasional dan Aspek Internasional, (Bandung: Mandar Maju, 2004), hlm. 38.

${ }^{25}$ Elwi Danil, Korupsi: Konsep, Tindak Pidana, dan Pemberantasannya, (Jakarta: Rajagrafindo Persada, 2012), hlm. 201.

${ }^{26} / \mathrm{bid}$. Lihat juga Oemar Seno Adji dalam Albert Hasibuan, Guru Besar Berbicara tentang Hukum, (Bandung: Alumni, 1985), hlm. 35.

${ }^{27}$ Ibid, hIm. 216-217. 
mendapat tempat atau diadopsi dalam Undang-Undang Pemberantasan Tindak Pidana Korupsi. Hanya saja dalam penerapannya perlu dipikirkan metode dan formula yang tepat agar tidak terjadi akses negatif.

Asas praduga bersalah (presumtion of guilty) dipandang sangat urgen untuk dapat dimuat dalam Undang-Undang Pemberantasan Tindak Pidana Korupsi dan dipandang urgen juga untuk dapat diterapkan dengan segera, karena modus operandi dari kasuskasus korupsi yang semakin canggih dan modern, sering dikategorikan sebagai invisible crime yang sangat sulit memperoleh prosedural pembuktiannya dan juga karena kejahatan korupsi yang dikategorikan sebagai extra ordinary crime yang juga membutuhkan extra ordinary enforcement dan extra ordinary measures. Penerapan asas praduga bersalah (presumtion of guilty) ini sebaiknya dibatasi hanya dalam hal pembuktian di hadapan persidangan saja, melalui metode pembalikan beban pembuktian. Penerapan asas praduga bersalah (presumtion of guilty) yang bersinergi melalui metode pembalikan beban pembuktian tersebut, diharapkan mampu mengeliminasi tingkat kesulitan pembuktian yang dihadapi selama ini dalam pemberantasan tindak pidana korupsi.

Ketentuan mengenai pembalikan beban pembuktian ini sudah diatur dalam UUPTK, hanya saja terdapat kelemahan mendasar dari ketentuan pembalikan beban pembuktian dan ketentuan mengenai gratifikasi tersebut, yaitu terletak pada tidak adanya ketentuan mengenai bagaimana prosedur pembalikan beban pembuktian tersebut seharusnya dilaksanakan di muka persidangan.Fakta ini membuktikan bahwa pengaturan ketentuan gratifikasi (hukum materil) melalui pembalikan beban pembuktian dengan tujuan untuk mengembalikan aset korupsi dari tangan terdakwa, tidak didukung oleh hukum acara (hukum formil). Hal inilah yang mengakibatkan ketentuan pembalikan beban pembuktian sebagaimana disebutkan, bukan merupakan ketentuan pembalikan beban pembuktian dalam bentuk murni/aslinya (genuine reversal of burden of proof), melainkan bersifat terbatas (limited reversal of burden of proof atau balanced probability principle) selama ini dimuat dalam UUPTK.

Melalui proses pembuktian inilah ditentukan apakah kekuatan pembuktian dari setiap alat bukti akan menjadikan seorang terdakwa dibebaskan (vrijspraak), dilepaskan dari segala tuntutan (onstlag van alle rechtsvervolging), atau dipidana. Di tengah kebuntuan proses hukum pembuktian untuk menghadapkan para pelaku korupsi kehadapan proses peradilan pidana, penerapan pembalikan beban pembuktian oleh sementara ahli hukum diyakini mampu mengeliminasi tingkat kesulitan pembuktian. ${ }^{28}$

Satjipto Rahardjo, menyatakan bahwa sudah waktunya bangsa Indonesia mencanangkan bahaya korupsi sebagai keadaan darurat. Karena keadaannya darurat maka juga mesti ditangani dengan cara berpikir darurat, cara bertindak darurat

\footnotetext{
${ }^{28} /$ bid, hlm. 201.
} 
dan dengan petinggi hukum yang mampu melakukan terobosan yang bersifat darurat. ${ }^{29}$ Di sisi lain, usaha untuk membe-rantas korupsi sudah menjadi masalah global, bukan lagi nasional atau regional. Gejala korupsi ada pada setiap negara terutama yang sedang membangun, sudah hampir menjadi conditio sine qua non. Ada usaha terutama karena desakan rakyat banyak agar korupsi dibabat habis kalau perlu dengan hukum darurat, seperti dengan pidana yang berat, pembebasan penanganan korupsi dari instansi normal ke suatu badan independen yang dijamin integritasnya, dan sistem pembalikan beban pembuktian. ${ }^{30}$

Berbicara mengenai korupsi tidak sekedar pemidanaan saja, tetapi bagaimana kebijakan hukum pidana menghadapi invisible crime tersebut. Perhatian dan peran hukum pidana terhadap perbuatan yang masuk dalam kategori sebagai "tindak pidana korupsi," baik yang eksplisitas ada maupun tidak ada pengaturannya dalam hukum pidana positif di Indonesia. ${ }^{31}$ Bila dikaji dari perspektif kebijakan hukum pidana, eksistensi pembalikan beban pembuktian mengandung prevensi khusus bagi tindak pidana korupsi yang dikategorikan sebagai extra ordinary crime yang juga membutuhkan extra ordinary enforcement dan extra ordinary measures.
Berangkat dari kenyataan yang diuraikan di atas, maka dalam rangka penanggulangan masalah korupsi di Indonesia diperlukan adanya kebijakan hukum pidana. Kebijakan hukum pidana tersebut harus dikonsentrasikan pada kebijakan formulatif, yaitu kebijakan yang mengarah pada upaya pembaharuan hukum pidana, khususnya perubahan dalam substansi hukum dari UUPTK.

Penelitian sejenis pernah diteliti oleh penulis lain, tetapi substansinya berbeda dengan penelitian ini. Maria Silvya E. Wangga pernah meneliti tentang mekanisme pembalikan beban pembuktian tindak pidana pencucian uang. Dalam penelitiannya menyimpulkan penerapan prinsip pembalikan beban pembuktian dalam tindak pidana pencucian hanya dilakukan oleh terdakwa atas harta kekayaan yang diduga diperoleh dari tindak pidana korupsi, penyuapan, narkotika, psikotropika, penyelundupan tenaga kerja, penyelundupan migrant, dibidang perbankan, pasar modal, perasuransian, kepabeanan, cukai, perdagangan manusia, perdagangan senjata gelap, terorisme, penculikan, pencurian, penggelapan, penipuan, pemalsuan uang, perjudian, prostitusi, perpajakan, kehutanan, ingkungan hidup, kelautan dan perikanan atau tindak pidana lain yang diancam pidana penjara 4 (empat) tahun atau lebih. Untuk mendukung penerapan prinsip pembalikan

\footnotetext{
${ }^{29}$ Achmad Ali, Keterpurukan Hukum di Indonesia, Penyebab dan Solusinya, (Jakarta: Ghalia Indonesia, 2001), hlm. 16.

${ }^{30}$ Andi Hamzah, Perbandingan Pemberantasan Korupsi di Berbagai Negara, (Jakarta: Sinar Grafika, 2008), hlm. v.

${ }^{31}$ Indriyanto Seno Adji, Korupsi Kebijakan Aparatur Negara \& Hukum Pidana, (Jakarta: Diadit Media 2009), hlm. 315.
} 
beban pembuktian dalam tindak pidana pencucian uang perlu menerapkan metode penelusuran dan pengungkapan harta kekayaan serta didukung oleh data-data berupa laporan harta kekayaan pejabat negara sebelum, selama dan sesudah menjabat, sehingga dapat membuktikan semua rumusan unsur tindak pidana pencucian uang. ${ }^{32}$

Mulyanto pernah meneliti tentang praktik pembatasan pembalikan beban pembuktian dalam pengadilan tipikor (studi pada perkara korupsi RAPBD Kota Semarang di Pengadilan Tipikor Kota Semarang). Dalam penelitiannya menyimpulkan bahwa penerapan sistem pembuktian terbalik dirasakan sangat efektif dalam menangani tindak pidana korupsi, paling tidak pembuktian tersebut untuk meminimalisir adanya kerugian negara akibat tindak pidana korupsi. Sebab pada prinsipnya tujuan dari pembuktian terbalik untuk melacak keuangan negara yang dialihkan menjadi milik pribadi. Perkara korupsi yang terjadi di Pengadilan Tindakan Pidana Korupsi (Tipikor) Semarang, pada dasarnya tidak merugikan keuangan negara, karena masuk unsur tindak pidana suap. Adapun tidak terjadinya kerugian negara dan tergolong sebagai salah satu syarat untuk dilakukannya pembuktian terbalik, namun karena masuk perkara suap yang tidak merugikan keuangan negara maka pembuktian terbalik dalam persidangan tidak dilakukan. ${ }^{33}$

Wahyu Wiriadinata menulis tentang korupsi dan pembalikan beban pembuktian. Dalam penelitiannya menyimpulkan untuk mencegah dan mengatasi tindak pidana korupsi di Indonesia serta untuk menghilangkan tindak pidana korupsi, paling tidak mengurangi kualitas maupun kuantitasnya, maka tidak cukup dilakukan pendekatan secara yuridis, tapi juga pendekatan sosiologis dan politis. Khususnya dalam penanganan tindak pidana korupsi, sistem hukum acara pidana untuk penanganan dan penyelesaiannya harus seefektif mungkin diterapkan. Tidak cukup dengan menggunakan sistem pembuktian yang konvensional, tetapi nampaknya harus digunakan sistem pembuktian terbalik murni. Namun, demikian pemberlakuan sistem pembuktian terbalik murni pure reversalborden of proof akan menimbulkan pelanggaran terhadap asas hukum praduga tidak bersalah, nonself incrimination, pelanggaran terhadap hak asasi manusia, dan hak tidak untuk bungkam, juga akan menimbulkan chaos birokrasi. ${ }^{34}$

Penulis sendiri pernah meneliti tentangpembalikan beban pembuktian sebagai kebijakan hukum pidana dalam undang-undang tindak pidana korupsi. Dalam penelitiannya menjelaskan urgensi

\footnotetext{
${ }^{32}$ Maria Silvya E. Wangga, Mekanisme Pembalikan Beban Pembuktian Tindak Pidana Pencucian Uang, Jurnal Hukum Adil, Volume 3, Nomor 2, 2015, hlm. 351.

${ }^{33}$ Mulyanto,Praktik Pembatasan Pembalikan Beban Pembuktian dalam Pengadilan Tipikor (Studi Pada Perkara Korupsi RAPBD Kota Semarang di Pengadilan Tipikor Kota Semarang), Jurnal Jurisprudence, Volume 6, Nomor 2, September 2016, hIm. 124.

${ }^{34}$ Wahyu Wiriadinata,Korupsi dan Pembalikan Beban Pembuktian,Jurnal Konstitusi, Volume 9, Nomor 2, Juni 2012, hlm. 330.
} 
pembalikan beban pembuktian sebagai kebijakan hukum pidana dalam undangundang tindak pidana korupsi. ${ }^{35}$

Penelitian-penelitian terdahulu tersebut tidak sama kajian dan substansinya dengan penelitian ini, sehingga penelitian ini akan menghasilkan suatu kebaruan (novelty). Adapun permasalahan dalam penelitian ini antara lain, Pertama, bagaimanakah kebijakan hukum pidana terkait beban pembuktian pada tindak pidana korupsi dalam rangka pengembalian kerugian keuangan negara? Kedua, bagaimana seharusnya pembaharuan kebijakan hukum pidana terkait beban pembuktian dapat digunakan sebagai istrumen hukum dalam rangka pengembalian kerugian keuangan negara? Hasil yang diharapkan dari penelitian ini menjelaskan tentang pembaharuan kebijakan hukum pidana terkait beban pembuktian yang dapat digunakan sebagai istrumen hukum dalam rangka pengembalian kerugian keuangan negara.

\section{Metode Penelitian}

Penelitian ini termasuk jenis penelitian hukum normatif/yuridis normatif, yaitu dilakukan dengan cara meneliti bahan pustaka atau data sekunder yang berhubungan dengan rumusan permasalahan yang telah ditetapkan. ${ }^{36}$ Bahan hukum penelitian ini bersumber dari penelitian kepustakaan atau library research. Dalam penelitian Kepustakaan data yang diperoleh berupa data sekunder, yakni data yang telah terolah atau tersusun, ${ }^{37}$ yang meliputi bahan hukum primer, bahan hukum sekunder dan bahan hukum tersier.

Teknik pengumpulan bahan hukum dilakukan melalui penelitian kepustakaan (library research) untuk mendapatkan konsepsi teori atau doktrin, pendapat atau pemikiran konseptual dan terdahulu yang berhubungan dengan obyek telaahan, yang dapat berupa peraturan perundangundangan, buku, tulisan ilmiah dan karyakarya ilmiah lainnya. Pada tahap awal pengumpulan data, dilakukan inventarisir terhadap seluruh data dan dokumen yang relevan dengan topik pembahasan. Selanjutnya dilakukan pengkategorian datadata tersebut berdasarkan rumusan masalah yang telah ditetapkan.

Data yang diperoleh dikelompokkan dan disusun secara sistematis dan selanjutnya dianalisis secara analisis kualitatif, yaitu analisis berupa kalimat dan uraian. ${ }^{38}$ Metode yang digunakan analisis yuridis, yaitu analisis mendasarkan pada teori-teori, konsep dan peraturan perundangundangan. Setelah itu, data yang diperoleh disusun secara sistematis dan untuk selanjutnya analisis kualitatif dipakai untuk mencapai penjelasan yang dibahas.

\footnotetext{
${ }^{35}$ Afrianto Sagita,Pembalikan Beban Pembuktian Sebagai Kebijakan Hukum Pidana Dalam UndangUndang Tindak Pidana Korupsi, Jurnal Hukum Respublica, Volume 17, Nomor 1, Tahun 2017, hlm. 29.

${ }^{36}$ Soerjono Soekanto dan Sri Mamudji, Penelitian Hukum Normatif (Suatu Tinjauan Singkat), (Jakarta: Raja Grafindo Persada, 2009), hlm. 13-14.

${ }^{37}$ Soerjono Soekanto, Pengantar Penelitian Hukum, (Jakarta: Penerbit Universitas Indonesia UI-Press, 2006), hlm. 12.

${ }^{38}$ Achmad Ali, Menjelajahi Kajian Empiris Terhadap Hukum, (Jakarta: Yasrif Watampone, 2008), hlm. 188.
} 


\section{Pembahasan}

Pembaharuan Kebijakan Hukum Pidana Terkait Beban Pembuktian yang Dapat Digunakan Sebagai Istrumen Hukum Dalam Rangka Pengembalian Kerugian Keuangan Negara

Istilah "kebijakan" dalam tulisan ini diambil dari istilah "policy" (Inggris) atau "politiek" (Belanda). ${ }^{39}$ Bertolak dari kedua istilah asing ini maka istilah "kebijakan hukum pidana" dapat pula disebut dengan istilah "politik hukum pidana". ${ }^{40}$ Dalam kepustakaan asing istilah "politik hukum pidana" ini sering dikenal dengan berbagai istilah, antara lain "penal policy", "criminal law policy" atau "strafrechtspolitiek". ${ }^{41}$

Menurut Sudarto, "politik hukum" adalah:

"1. Usaha untuk mewujudkan per-aturanperaturan yang baik sesuai dengan keadaan dan situasi pada suatu saat. ${ }^{42}$

2. Kebijakan dari negara melalui badanbadan yang berwenang untuk menetapkan peraturan-peraturan yang dikehendaki yang diperkirakan bisa digunakan untuk mengekspresikan apa yang terkandung dalam masyarakat dan untuk mencapai apa yang dicita-citakan". ${ }^{43}$

Bertolak dari pengertian tersebut Sudarto selanjutnya menyatakan bahwa melaksanakan "politik hukum pidana" berarti mengadakan pemilihan untuk mencapai hasil perundang-undangan pidana yang paling baik dalam arti memenuhi syarat keadilan dan daya guna. ${ }^{44}$ Dalam kesempatan lain, beliau menyatakan bahwa melaksanakan "politik hukum pidana" berarti, usaha mewujudkan peraturan perundang-undangan pidana yang sesuai dengan keadaan dan situasi pada suatu waktu dan untuk masa-masa yang akan datang. ${ }^{45}$

Pengertian demikian terlihat pula dalam definisi "penal policy" dari Marc Ancel yang menyatakan sebagai suatu ilmu sekaligus seni yang bertujuan untuk memungkinkan peraturan hukum positif dirumuskan secara lebih baik. ${ }^{46}$ Menurut A. Mulder, "strafrechtspolitiek" ialah garis kebijakan untuk menentukan:47

"1. Seberapa jauh ketentuan-ketentuan pidana yang berlaku perlu diubah atau diperbaharui.

\footnotetext{
${ }^{39}$ Barda Nawawi Arief, Bunga Rampai Kebijakan Hukum Pidana, (Bandung: PT Citra Aditya Bakti, 2002), hIm. 24.

40 lbid.

${ }^{41}$ /bid.

${ }^{42}$ Ibid. Lihat juga Sudarto, Hukum dan Hukum Pidana, (Bandung: Alumni, 1981), hlm. 159.

${ }^{43} \mathrm{Ibid}$, hlm. 25. Lihat juga Sudarto, Hukum Pidana dan Perkembangan Masyarakat, (Bandung: Sinar Baru, 1983), hlm. 20.

${ }^{44}$ Sudarto, Hukum dan...Op.Cit., hlm. 161.

${ }^{45}$ Sudarto, Hukum Pidana...Op.Cit., hlm. 93 dan 109.

${ }^{46}$ /bid.

${ }^{47}$ Ibid, hlm. 25-26. Lihat juga A. Mulder, "Strafrechtspolitiek" Delikt en Delinkwent, (Mei 1980), hlm. 333.
} 
2. Apa yang dapat diperbuat untuk mencegah terjadinya tindak pidana.

3. Cara bagaimana penyidikan, penuntutan, peradilan dan pelaksanaan pidana harus dilaksanakan".

Definisi Mulder di atas bertolak dari pengertian "sistem hukum pidana" menurut Marc Ancel yang menyatakan, bahwa tiap masyarakat yang terorganisir memiliki sistem hukum pidana yang terdiri dari: ${ }^{48}$

"1. Peraturan-peraturan hukum pidana dan sanksinya.

1. Suatu prosedur hukum pidana.

2. Suatu mekanisme pelaksanaan (pidana)".

Usaha dan kebijakan untuk membuat peraturan hukum pidana yang baik, pada hakikatnya tidak dapat dilepaskan dari tujuan penanggulangan kejahatan. Jadi, kebijakan atau politik hukum pidana juga merupakan bagian dari politik kriminal. ${ }^{49}$ Oleh karena itu, sering pula dikatakan bahwa politik atau kebijakan hukum pidana juga merupakan bagian dari kebijakan penegakan hukum (law enforcement policy). ${ }^{50}$

Sebagaimana telah disinggung "korupsi telah merusak sistem dan institusi sosial, ekonomi, mental dan citra aparatur negara. Indonesia mengalami sulitnya memberantas tindak pidana korupsi yang terus terjadi di seluruh instansi dan kegiatan pembangunan, dengan banyak variasi modus operandi. ${ }^{51}$ Apabila tidak ada perbaikan maka kondisi tersebut akan sangat membahayakan kelangsungan hidup bangsa. ${ }^{52}$

Romli Atmasasmita perbuatan korupsi merupakan perampasan hak ekonomi dan hak sosial rakyat Indonesia ${ }^{53}$ maka Indonesia akan sangat sulit berkembang ke fase negara maju. Banyak koruptor di Indonesia yang selama ini tidak tersentuh hukum pidana karena alasan pembuktian yang sulit. Mereka cenderung berlindung di balik asas praduga tak bersalah (presumption of innocence). Asas praduga bersalah (presumtion of guilty) dipandang sangat urgen dimuat dalam UUPTK juga urgen diterapkan segera, karena modus operandi semakin canggih dan modern. Kasus korupsi sering dikategorikan sebagai invisible crime karena sulit memperoleh prosedural pembuktiannya. Kejahatan korupsi juga dikategorikan sebagai extra ordinary crime membutuhkan extra ordinary enforcement dan extra ordinary measures. Hanya saja dalam penerapannya perlu dipikirkan metode dan formula yang tepat agar tidak terjadi akses negatif.

KPK dituntut untuk tidak lagi menggunakan cara-cara konvensional dalam menangani kasus korupsi yang masif, tetapi harus menggunakan cara yang progresif. Salah satunya dengan jalan

\footnotetext{
${ }^{48} /$ bid.

${ }^{49} /$ bid.

${ }^{50} / \mathrm{bid}$.

${ }^{51}$ Feri Wibisono, Menyongsong Era... Loc. Cit.

${ }^{52}$ Buku I Rencana... Op.Cit. hlm. 5-10.

${ }^{53}$ Lilik Mulyadi, Tindak Pidana... Loc. Cit.
} 
memberi ruang agar asas praduga bersalah (presumption of guilty) mendapat tempat atau diadopsi dalam UUPTK.

Penerapan asas praduga bersalah (presumption of guilty) ini sebaiknya dibatasi hanya dalam hal pembuktian dihadapan persidangan saja, melalui metode pembalikan beban pembuktian. Penerapan asas praduga bersalah (presumption of guilty) yang bersinergi melalui metode pembalikan beban pembuktian tersebut, diharapkan mampu mengeliminasi tingkat kesulitan pembuktian yang dihadapi dalam pemberantasan tindak pidana korupsi.

Ketentuan mengenai pembalikan beban pembuktian ini sudah diatur dalam UUPTK, hanya saja terdapat kelemahan mendasar, yaitu terletak pada tidak adanya ketentuan mengenai prosedur pembalikan beban pembuktian tersebut dilaksanakan di muka persidangan. Fakta ini membuktikan bahwa pengaturan ketentuan gratifikasi (hukum materil) melalui pembalikan beban pembuktian dengan tujuan untuk mengembalikan aset korupsi dari tangan terdakwa, tidak didukung oleh hukum acara (hukum formal).

Praktik pencegahan dan pemberantasan korupsi di Indonesia terbukti jauh lebih maju dibandingkan dengan Konvensi Perserikatan Bangsa-Bangsa (PBB) dalam hal prosedur pembuktian terbalik yang bersifat wajib (mandatory), tetapi hanya dapat dilakukan di muka sidang pengadilan.

Berbicara tentang pembuktian maka berkaitan dengan teori-teori sistem pembuktian. Pada hakikatnya dalam rangka menerapkan pembuktian atau hukum pembuktian hakim selalu bertitik tolak kepada sistem pembuktian dengan tujuan mengetahui cara meletakkan suatu hasil pembuktian terhadap perkara yang sedang diadilinya. Untuk itu, secara teoritis guna penerapan sistem pembuktian pada asasnya dikenal 3 (tiga) teorisebagai berikut. $^{54}$

"1. Sistem pembuktian menurut undangundang secara positif (positief wettelijke bewijs theorie). Menurut teori ini, sistem pembuktian positif bergantung kepada alat-alat bukti sebagaimana disebut secara limitatif dalam undang-undang. Singkatnya, undang-undang telah menetukan tentang adanya alat-alat bukti mana yang dapat dipakai hakim, cara bagaimana hakim harus mempergunakannya, kekuatan alat-alat bukti tersebut dan bagaimana caranya hakim harus memutus terbukti atau tidaknya perkara yang sedang diadili.

2. Sistem pembuktian menurut keyakinan hakim (conviction intime/ conviction raisonce). Pada sistem pembuktian berdasarkan keyakinan hakim, maka hakim dapat menjatuhkan putusan berdasarkan keyakinan belaka dengan tidak terikat oleh suatu peraturan. Dalam perkembangannya, sistem pembuktian berdasarkan keyakinan hakim mempunyai dua bentuk polarisasi,

54/bid, hlm. 243. 
yaitu "conviction intime", bahwa kesalahan terdakwa bergantung kepada keyakinan belaka sehingga hakim tidak terikat oleh suatu peraturan dengan sistem pembuktian. Sistem pembuktian "conviction raisonce" asasnya identik sistem "conviction intime", yaitu keyakinan hakim tetap memegang peranan penting untuk menentukan tentang kesalahan terdakwa, tetapi penerapan keyakinan tersebut dilakukan secara selektif dalam arti dibatasi oleh alasan-alasan jelas dan rasional dalam mengambil keputusan.

3. Sistem pembuktian menurut undangundang secara negatif (negatief wettelijke bewijs theorie). Pada prinsipnya, sistem pembuktian menurut undang-undang secara negatif menentukan bahwa hakim hanya boleh menjatuhkan pidana kepada terdakwa apabila alat bukti tersebut secara limitatif ditentukan oleh undang-undang dan didukung pula adanya keyakinan hakim terhadap eksistensi alat-alat bukti tersebut. Secara historis ternyata sistem pembuktian negatif merupakan peramuan antara sistem pembuktian undang-undang secara positif dan sistem pembuktian berdasarkan keyakinan hakim".

Adami Chazawi mengklasifikasikan teori tentang sistem pembuktian yang telah dikenal dalam doktrin hukum acara pidana, sebagai berikut. ${ }^{55}$

"1. Sistem keyakinan belaka (conviction in time). Menurut sistem ini, hakim dapat menyatakan telah terbukti kesalahan terdakwa melakukan tindak pidana yang didakwakan dengan didasarkan pada keyakinannya saja, dan tidak perlu mempertimbangkan dari mana (alat bukti) dia memperoleh dan alasan-alasan yang dipergunakan serta bagaimana caranya dalam membentuk keyakinan tersebut.

2. Sistem keyakinan dengan alasan logis (laconviction in raisonne). Sistem ini lebih maju sedikit dari pada sistem yang pertama, walaupun kedua sistem dalam hal menarik hasil pembuktian tetap didasarkan pada keyakinan. Disebut lebih maju karena dalam sistem ini dalam hal membentuk dan menggunakan keyakinan hakim untuk menarik kesimpulan tentang terbuktinya kesalahan terdakwa melakukan tindak pidana, didasarkan pada alasan-alasan yang logis. Walaupun alasan-alasan itu dengan menggunakan alat-alat bukti baik yang ada disebutkan dalam undang-undang maupun diluar undang-undang.

3. Sistem pembuktian melulu undangundang (positief wettelijk bewijs theorie). Ada kalanya sistem

${ }^{55}$ Adami Chazawi, Hukum Pembuktian Tindak Pidana Korupsi, (Bandung: Alumni, 2008, hlm. 24-28. 
pembuktian ini disebut dengan sistem menurut undang-undang secara positif. Maksudnya, dalam hal membuktikan kesalahan terdakwa melakukan tindak pidana didasarkan semata-mata pada alat-alat bukti serta cara-cara mempergunakannya yang telah ditentukan terlebih dulu dalam undang-undang.

4. Sistem pembuktian menurut undangundang secara terbatas (Negatief wettelijk bewijstheorie). Menurut sistem ini, dalam hal membuktikan kesalahan terdakwa melakukan tindak pidana yang didakwakan kepadanya, hakim tidak sepenuhnya mengandalkan alat-alat bukti serta dengan cara-cara yang ditentukan oleh undang-undang".

Sistem pembuktian yang dianut Kitab Undang-Undang Hukum Acara Pidana (KUHAP) dan praktik peradilan antara lain: 56

"1. Sistem pembuktian menurut KUHAP, menganutsistem pembuktian secara negatif (negatief wettelijk bewijstheorie). Hal ini tampak pada ketentuan Pasal 183 KUHAP yang mengatakan bahwa: "Hakim tidak boleh menjatuhkan pidana kepada seorang, kecuali apabila dengan sekurang-kurangnya dua alat bukti yang sah ia memperoleh keyakinan bahwa suatu tindak pidana benarbenar terjadi dan bahwa terdakwalah yang bersalah melakukannya". ${ }^{57}$
2. Sistem pembuktian yang terjadi dalam praktik peradilan tampaknya akan mengarah kepadasistem pembuktian menurut undang-undang secara positif (positief wettelijk bewijstheorie). Hal ini karena aspek "keyakinan" pada Pasal 183 KUHAP tidak diterapkan secara limitatif. Apabila dalam suatu putusan hakim pada "diktum atau amar" tidak mencantumkan rumusan keyakinannya yang berupa: "secara sah dan meyakinkan", kelalaian tersebut tidak menyebabkan putusan batal demi hukum. Akan tetapi, praktiknya dalam tingkat banding atau kasasi hanya akan diperbaiki dengan penambahan kata-kata "secara sah dan meyakinkan" dalam amar atau diktum putusan".

Dikaji dari perspektif ilmu pengetahuan hukum pidana dikenal ada 3 (tiga) teori tentang pembuktian. Secara universal ketiga teori tentang beban pembuktian tersebut hakikatnya terdapat di negara Indonesia maupun di beberapa negara seperti di negara Malaysia, United Kingdom of Great Britain (Inggris), Hongkong maupun di negara Republik Singapura, yaitu ${ }^{58}$

"1. Beban pembuktian pada penuntut umum, konsekuensi logis teori beban pembuktian penuntut umum harus mempersiapkan alat-alat bukti dan barang bukti secara akurat, sebab jika tidak akan susah meyakinkan

${ }^{56}$ Lilik Mulyadi, Tindak Pidana... Op. Cit., hlm. 248.

${ }^{57}$ Undang-Undang tentang Hukum Acara Pidana, Undang-Undang Nomor 8 Tahun 1981.

${ }^{58}$ Lilik Mulyadi, Pembalikan Beban Pembuktian Tindak Pidana Korupsi, (Bandung: Alumni, 2007), hIm. 101-103. 
hakim tentang kesalahan terdakwa. Konsekuensi logis beban pembuktian ada pada penuntut umum ini berkorelasi asas praduga tidak bersalah dan aktualisasi asas tidak mempersalahkan diri sendiri (non self incrimination). Teori beban pembuktian ini dikenal di Indonesia bahwa ketentuan Pasal 66 KUHAP dengan tegas menyebutkan bahwa tersangka atau terdakwa tidak dibebani kewajiban pembuktian maka beban pembuktian seperti ini dapat dikategorikan beban pembuktian biasa atau konvensional.

2. Beban pembuktian pada terdakwa, dalam konteks ini terdakwa berperan aktif menyatakan bahwa dirinya bukan sebagai pelaku tindak pidana. Oleh karena itu, terdakwalah di depan sidang pengadilan yang akan menyiapkan segala beban pembuktian dan bila tidak dapat membuktikan, terdakwa dinyatakan bersalah melakukan tindak pidana. Pada asasnya, teori beban pembuktian jenis ini dinamakan teori pembalikan beban pembuktian (omkering van het bewijslast atau shifting burden of proof I onus of proof). Dikaji dari perspektif teoritis dan praktik teori beban pembuktian ini dapat diklasifikasikan lagi menjadi pembalikan beban pembuktian yang bersifat murni maupun bersifat terbatas (limited burden of proof). Pada hakikatnya, pembalikan beban pembuktian tersebut merupakan suatu penyimpangan hukum pembuktian dan juga merupakan suatu tindakan luar biasa terhadap tindak pidana korupsi.

3. Beban pembuktian berimbang, konkretisasi asas ini baik penuntut umum maupun terdakwa dan/atau penasihat hukumnya saling membuktikan di depan persidangan. Lazimnya penuntut umum akan membuktikan kesalahan terdakwa, sedangka terdakwa beserta penasihat hukum akan membuktikan sebaliknya bahwa terdakwa tidak terbukti secara sah dan meyakinkan bersalah melakukan tindak pidana yang didakwakan. Dalam kepustakaan ilmu hukum asas beban pembuktian ini dinamakan juga asas pembalikan beban pembuktian "berimbang" seperti di kenal di Amerika Serikat dan juga di Indonesia".

Satjipto Rahardjo menyatakan bahwa sudah waktunya Indonesia mencanangkan bahaya korupsi sebagai keadaan darurat. Karena keadaannya darurat maka juga mesti ditangani dengan cara berpikir darurat, cara bertindak darurat dan dengan petinggi hukum yang mampu melakukan terobosan yang bersifat darurat. ${ }^{59} \mathrm{Di}$ sisi lain, usaha untuk memberantas korupsi sudah menjadi masalah global, bukan lagi nasional atau regional. Gejala korupsi ada pada setiap negara terutama yang sedang membangun, sudah hampir menjadi conditio sine qua non. Ada usaha terutama karena

${ }^{59}$ Achmad Ali, Keterpurukan Hukum...Loc.Cit. 
desakan rakyat banyak agar korupsi dibabat habis kalau perlu dengan hukum darurat, seperti dengan pidana yang berat, pembebasan penanganan korupsi dari instansi normal ke suatu badan independen yang dijamin integritasnya, dan sistem pembalikan beban pembuktian. ${ }^{60}$

Menurut Lilik Mulyadi, beban pembuktian pada penuntut umum, konsekuensi logis teori beban pembuktian ini bahwa penuntut umum harus mempersiapkan alatalat bukti dan barang bukti secara akurat, sebab jika tidak demikian akan susah meyakinkan hakim tentang kesalahan terdakwa. Penuntut umum berkorelasi asas praduga tidak bersalah dan aktualisasi asas tidak mempersalahkan diri sendiri (non self incrimination).

Peneliti setuju dengan pendapat Lilik Mulyadi, teori beban pembuktian ini dianut dalam Pasal 66 KUHAP, yaitu "tersangka atau terdakwa tidak dibebani kewajiban pembuktian." Secara jelas dan terang dinyatakan dalam Penjelasan atas UndangUndang Nomor 8 Tahun 1981 tentang Hukum Acara Pidana dinyatakan bahwa "ketentuan ini adalah penjelmaan dari asas "praduga tak bersalah".Dapat dikatakan bahwa dengan memuat/mengadopsi sistem pembalikan beban pembuktian dan menuangkannya dalam bentuk norma dalam ketentuanketentuan klausul pasal demi pasal dalam UUPTK, merupakan bentuk pengingkaran terhadap asas praduga tak bersalah. Oleh karena itu, sudah selayaknyajika pembentuk undang-undang tetap menginginkan agar dalam UUPTK tetap dimuat mengenai sistem pembalikan beban pembuktian. Selanjutnya, haruslah dicarikan payung hukumnya, yaitu dengan jalan menjadikan asas praduga bersalah menjadi pondasinya/ landasan filosofis yang berfungsi sebagai payung hukumnya. Kemudian dari tataran asas diturunkan menjadi norma, sehingga dengan demikian ketentuan mengenai pembalikan beban pembuktian dapat dicantumkan dalam klausul pasal demi pasal dalam UUPTK.

Korupsi tidak sekedar pemidanaan saja, tetapi bagaimana kebijakan hukum pidana menghadapi invisible crime. Perhatian dan peran hukum pidana terhadap perbuatan yang masuk dalam kategori sebagai "tindak pidana korupsi," baik yang eksplisitas ada maupun tidak ada pengaturannya dalam hukum pidana positif di indonesia. Bila dikaji dari perspektif kebijakan hukum pidana, eksistensi pembalikan beban pembuktian mengandung prevensi khusus bagi tindak pidana korupsi yang dikategorikan sebagai extra ordinary crime yang juga membutuhkan extra ordinary enforcement dan extra ordinary measures.

\section{Referensi}

Achmad Ali. 2001. Keterpurukan Hukum di Indonesia, Penyebab dan Solusinya. Jakarta: Ghalia Indonesia. 2008. Menjelajahi Kajian Empiris Terhadap Hukum. Jakarta: Yasrif Watampone.

${ }^{60}$ Andi Hamzah, Perbandingan Pemberantasan... Loc. Cit. 
A. Djoko Sumaryanto. 2009. Pembalikan Beban Pembuktian Tindak Pidana Korupsi dalam Rangka Pengembalian Kerugian Keuangan Negara. Jakarta: Prestasi Pustakaraya.

Adami Chazawi. 2008. Hukum Pembuktian Tindak Pidana Korupsi. Bandung: Alumni.

Afrianto Sagita.Pembalikan Beban Pembuktian Sebagai Kebijakan Hukum Pidana Dalam UndangUndang Tindak Pidana Korupsi. Jurnal Hukum Respublica. Volume 17. Nomor 1. Tahun 2017.

Andi Hamzah. 2008. Perbandingan Pemberantasan Korupsi di Berbagai Negara. Jakarta: Sinar Grafika.

Albert Hasibuan. 1985. Guru Besar Berbicara tentang Hukum. Bandung: Alumni.

Alpiner Sinaga. 2005. Korupsi, Bias dan Strategi Penyidikan. Jakarta: Markas Besar Kepolisian Negara Republik Indonesia.

Barda Nawawi Arief. 2002. Bunga Rampai Kebijakan Hukum Pidana. Bandung: PT Citra Aditya Bakti.

Denny Indrayana. 2008. Negeri Para Mafioso: Hukum di Sarang Penyamun. Jakarta: Kompas.

Elwi Danil. 2012. Korupsi: Konsep, Tindak Pidana, dan Pemberantasannya. Jakarta: Rajagrafindo Persada.

Ermansjah Djaja. 2010. Tipologi Tindak Pidana Korupsi di Indonesia. Bandung: Mandar Maju.

Feri Wibisono. Menyongsong Era Baru Pemberantasan Tindak Pidana
Korupsi. Media Hukum. Volume 1. Nomor 2. 2002.

Indriyanto Seno Adji. 2009. Korupsi Kebijakan Aparatur Negara \& Hukum Pidana. Jakarta: Diadit Media.

KPK. 2008. Buku I Rencana Stratejik KPK 2008-2011. Jakarta: Komisi Pemberantasan Korupsi.

Lilik Mulyadi. 2007. Tindak Pidana Korupsi di Indonesia Normatif, Teoritis, Praktik dan Masalahnya. Bandung: Alumni.

2007. Pembalikan Beban
Pembuktian Tindak Pidana
Korupsi. Bandung:Alumni.

Nur Basuki Minarno. Pembuktian Gratifikasi dan Suap dalam Tindak Pidana Korupsi. Yuridika. Majalah Fakultas Hukum UNAIR. Volume 20. Nomor 2 Maret 2005.

Majelis Tarjih dan Tajdid PP Muhammadiyah. 2006. Fikih Anti Korupsi Perspektif Ulama Muhammadiyah. Jakarta: Pusat Studi Agama dan Peradaban.

Maria Silvya E. Wangga. Mekanisme Pembalikan Beban Pembuktian Tindak Pidana Pencucian Uang. Jurnal Hukum Adil. Volume 3. Nomor 2. 2015.

Mulyanto.Praktik Pembatasan Pembalikan Beban Pembuktian dalam Pengadilan Tipikor (Studi Pada Perkara Korupsi RAPBD Kota Semarang di Pengadilan Tipikor Kota Semarang). Jurnal Jurisprudence. Volume 6. Nomor 2. September 2016. 
Romli Atmasasmita. 2002. Korupsi, Good Governance dan Komisi Anti Korupsi di Indonesia. Jakarta: Badan Pembinaan Hukum Nasional Departemen Kehakiman dan HAM RI. 2004. Sekitar Masalah Korupsi Aspek Nasional dan Aspek Internasional. Bandung: Mandar Maju.

Soerjono Soekanto dan Sri Mamudji. 2009. Penelitian Hukum Normatif (Suatu Tinjauan Singkat). Jakarta: Raja Grafindo Persada.
Soerjono Soekanto. 2006. Pengantar Penelitian Hukum. Jakarta: Penerbit Universitas Indonesia UIPress.

Sudarto. 1981. Hukum dan Hukum Pidana. Bandung: Alumni.

-_—_- 1983. Hukum Pidana dan Perkembangan Masyarakat. Bandung: Sinar Baru.

Wahyu Wiriadinata. Korupsi dan Pembalikan Beban Pembuktian. Jurnal Konstitusi. Volume 9. Nomor 2. Juni 2012. 